\title{
Antidiarrhoeal activity of leaf aqueous extracts of Olea europaea var. sylvestris in albino Wistar rats
}

\author{
Mohamed Zaouani, ${ }^{1}$ Fatima Yahiaoui, ${ }^{1}$ Nazli Nacer Bey, ${ }^{2}$ Meriem Hind Ben-Mahdi ${ }^{1,3}$ \\ ${ }^{1}$ Laboratory of Research, Health and Animal Productions, Higher National Veterinary School; ${ }^{2}$ Department of Forestry \\ and Nature Protection, Higher National Agronomic School; ${ }^{3}$ Higher School of Food Sciences and Agro-alimentary \\ Industries, Algiers, Algeria
}

\begin{abstract}
Olea europaea var. sylvestris, also named oleaster, is widely used by traditional medicine practitioners in Algeria to treat high blood pressure and diabetes. However, the antidiarrhoeal activity of this plant has not been scientifically evaluated. The main aim of the study deals with an investigation of three topics: the phytochemical screening, the acute toxicity, and antidiarrhoeal activity of the oleaster leaf aqueous extract. Acute oral toxicity study was carried out based on Organization for Economic Cooperation and Development 423 guideline. The extract was orally administered in wistar rats at a single dose of $2000 \mathrm{mg} / \mathrm{kg}$ body weight and the animals were observed for mortality, behavioral changes and other abnormal signs. Qualitative analysis of phytochemical con-
\end{abstract}

Correspondence: Mohamed Zaouani, Laboratory of Research, Health and Animal Productions, Higher National Veterinary School, Algiers, Algeria.

Tel.: $+213550655275-$ Fax: +213021669930 .

E-mail:m.zaouani@ensv.dz

Key words: Acute toxicity; Leaf aqueous extracts; Antidiarrhoeal activity; Phytochemical; Olea europaea var. sylvestris.

Contributions: MZ worked out the study and wrote the manuscript; ZM, FY and NN contributed in antidiarrhoeal activity analysis; MHB designed the research and supervised the study. All the authors read and approved the final manuscript.

Conflict of interest: the authors declare no potential conflict of interest.

Funding: none.

Received for publication: 11 June 2018.

Revision received: 28 October 2018.

Accepted for publication: 28 October 2018.

(C) Copyright M. Zaouani et al., 2018

Licensee PAGEPress, Italy

Journal of Biological Research 2018; 91:7614

doi:10.4081/jbr.2018.7614

This article is distributed under the terms of the Creative Commons Attribution Noncommercial License (by-nc 4.0) which permits any noncommercial use, distribution, and reproduction in any medium, provided the original author(s) and source are credited. stituents was carried out using standard methods developed by Harborne, Trease and Evans. Castor oil-induced diarrhoea tests and gastro intestinal motility assay were evaluated in rats to determine the antidiarrhoeal activity of the extract. In the acute toxicity study, the extract did not induce death or any sign of toxicity in treated rats. The preliminary phytochemical screening of the extract revealed the presence of saponins, flavonoids, and triterpenoids. The oleaster extract at oral doses of 100, 200 and 400 $\mathrm{mg} / \mathrm{kg}$ body weight showed a significant $(\mathrm{P}<0.05)$ antidiarrhoeal activity compared to the control group treated with castor oil induced diarrhoea, enteropooling and gastrointestinal motility assay, after charcoal meal administration. The oleaster leaf aqueous extract has shown a gradual response with increasing dose. The present study indicates that the oleaster leaf aqueous extract is safe with antidiarrhoeal property.

\section{Introduction}

Olea europaea subsp. europaea $L$ includes two varieties: cultivated and wild olive trees, respectively called europaea (cultivars) and sylvestris (oleaster) which are naturally distributed all around the Mediterranean region. ${ }^{1}$ The medicinal properties of the oleaster tree are mostly attributed to the leaves used in infusion or decoction. They have been widely used in traditional remedies in European and Mediterranean countries for their bioactive compounds. ${ }^{2}$ Previous investigations carried out on oleaster leaf extracts have demonstrated their ability to reduce blood sugar, cholesterol, and uric acid. They have also been used to treat high blood pressure and inflammation. ${ }^{3}$ However, there are few studies on antidiarrhoeal activity. Diarrhoea disease affects far more individuals than any other illness, especially in developing countries. In veterinary field, this disease is one of the leading causes of mortality of livestock and domestic pets. ${ }^{4}$ Diarrhoea is a gastrointestinal disorder characterized by an increase in stool frequency and the change of their consistency. ${ }^{5}$ In most cases, drug therapy is needed to control and treat diarrhoea. However, the conventional drugs are associated with adverse effects, like abdominal discomfort, dry mouth, nausea and constipation. Our goal is to apply the highest effective dose with the least adverse effects. Therefore, the World Health Organization encouraged studies for the treatment and prevention of diarrhoea diseases depending on traditional medicine practices. ${ }^{6}$ Hence, the present study aims to identify the phytochemical constituents, the acute toxic effects, and to demonstrate that the oleaster leaf extract can be used as a traditional antidiarrhoeal remedy. 


\section{Materials and Methods}

Fresh green oleaster leaves were collected in Summer 2014 at the coastal town Bejaia located in north east of Algeria, at the Mediterranean edge. A taxonomist from Botany Department National Agronomy High School, Algiers, authenticated the leaves. A voucher specimen was introduced in the herbarium of Health and Animal Production Research Laboratory of National Veterinary School, Algiers.

The aqueous extracts were obtained using the method developed by Guede et al..$^{7}$ Fifty grams of leaf powder were put in maceration with $500 \mathrm{~mL}$ of distilled water for 72 hours. The solution was then filtered using clean cotton wool and wattman paper $\mathrm{N}^{\circ} 1$. The extract obtained after filtration undergo evaporation under reduced pressure using a Rotavapor at $40^{\circ} \mathrm{C}$ then lyophilized by using the lyophilizer for 12 hours and the product collected was preserved in a refrigerator at $4{ }^{\circ} \mathrm{C}$ for further use.

\section{Experimental animals}

The study was performed on adult Wistar rats of both sexes with an average weight of $200 \pm 20 \mathrm{~g}$, obtained from the Pasteur Institute of Algiers. The witness animals and treated animals were maintained under standard environmental conditions (temperature: $24.0 \pm 1.0^{\circ} \mathrm{C}$, relative humidity: $55-65 \%$ and $12 \mathrm{~h}$ light/ dark cycle) and had free access to feed and water ad libitum. All studies were conducted in accordance with the guideline for the care and use of Laboratory Animals ${ }^{8,9}$ and approved by the Laboratory Research Council of National Veterinary High School of Algiers, Algeria.

\section{Preliminary phytochemical screening}

The preliminary phytochemical screening was performed qualitatively using several chemical tests to detect the presence or no of various classes of phytoconstituents in solution of the oleaster extract. Phytoconstituents like saponins, tannins, alkaloids, steroids, flavonoids, glycosides were identified by the change of the characteristic color of the different reagents used in accordance with the standard procedures described by Harborne ${ }^{10}$ and Trease and Evans. ${ }^{11}$

\section{Acute toxicity study}

Acute toxicity study was carried out in accordance with guidelines of Organization for Economic Cooperation and Development 423 for testing of chemicals. ${ }^{12}$ Five rats per sex were administered a single oral dose of $2000 \mathrm{mg} / \mathrm{kg}$ body weight while the control group received water vehicle. The rats were under continuous observation for $24 \mathrm{~h}$, then for further 14 days in order to record mortalities or/and occurrence of general signs and symptoms of toxicity.

\section{Antidiarrhoeal activity}

\section{Castor oil induced diarrhoea in rats}

The method of Awouters et al. ${ }^{13}$ was adopted. Thirty rats of both sexes were fasted for $18 \mathrm{~h}$ and divided into five groups of six animals. Group I rats were administered orally normal saline solution $(2 \mathrm{~mL} / \mathrm{kg})$ as the control group. Doses of 100, 200 and 400 $\mathrm{mg} / \mathrm{kg}$ body weight of oleaster leaf aqueous extract were administered orally to groups II, III and IV respectively, while the fifth group received orally the standard drug, loperamide $(5 \mathrm{mg} / \mathrm{kg}$ body weight). All rats were housed singly in metabolic cages with a transparent plastic container beneath the cage to collect faeces. After an hour of treatments, each of the rats was treated with $1 \mathrm{~mL}$ of castor oil orally. Rats were then observed for $6 \mathrm{~h}$. The total number of faeces (both diarrhoea and non-diarrhoea) released in the groups treated with the oleaster leaf extract was compared with the positive control group.

The total diarrhoea faeces for the control group were considered $100 \%$.

The results were expressed as a percentage of inhibition of diarrhoea.

The percentage of defecation inhibition was calculated as follows:

$\%$ of Defecation Inhibition of defecation $=(A-B) / A \times 100$

A indicates the average number of defecation caused by castor oil; $\mathrm{B}$ indicates the average number of defecation caused by drug or oleaster leaf extract.

\section{Gastrointestinal motility assay}

Gastrointestinal motility assay was performed according to Chitme et al. ${ }^{14}$ method. Experimental rats were fasted for 18 -h and then divided into five groups of six rats each and allowed free access to water. Group I rats were administered orally normal saline solution ( $2 \mathrm{~mL} / \mathrm{kg})$ as the control group. Doses of 100, 200 and $400 \mathrm{mg} / \mathrm{kg}$ body weight of oleaster leaf aqueous extract were administered orally to groups II, III and IV respectively, while the fifth group received orally the standard drug, loperamide $(5 \mathrm{mg} / \mathrm{kg}$ body weight). Thirty minutes after drug administration, $1 \mathrm{~mL}$ of charcoal meal (5\%) was administered orally to all animals and 30 min later, all the rats were euthanized and the abdomen was opened to measure the distance travelled by the activated charcoal. The results were expressed as percentage of the total length of the intestine from the pylorus to the caecum:

$$
\text { Inhibition }(\%)=(\text { Dcontrol }- \text { Dtreated }) / \text { Dcontrol } \times 100
$$

\section{Castor oil induced enteropooling}

The castor oil-induced enteropooling was carried out according to Robert et al. ${ }^{15}$ method. Rats of either sex were divided into five groups of six rats, each were fasted for $18 \mathrm{~h}$ with free access to water. Group I rats were administered orally normal saline solution (2 $\mathrm{mL} / \mathrm{kg}$ ) as the control group. Groups II, III, VI were given orally 100 $\mathrm{mg} / \mathrm{kg}, 200 \mathrm{mg} \mathrm{kg}$, and $400 \mathrm{mg} / \mathrm{kg}$ of the oleaster leaf extract. Group $\mathrm{V}$ received orally standard drug loperamide $(5 \mathrm{mg} / \mathrm{kg}$ body weight $)$ An hour later, $1 \mathrm{~mL}$ of castor oil was administered to each of the treated rats. Two hours later, the rats were euthanized, small intestine was removed after tying the ends, with a thread, and weighed. Intestinal contents were collected by extricating the faeces into a graduated tube to measure their volumes. The intestine was reweighed and the difference between full and empty intestines was calculated. The level of reduction in the volume and weight of intestinal content was calculated relative to the control Group.

$$
\text { Inhibition }(\%)=(\text { Wcontrol }- \text { Wtreated }) /(\text { Wcontrol }) \times 1000
$$

where Wcontrol refers to the weight of intestinal content in control group; Wtreated refers to the weight of intestinal content in treated group.

\section{Statistical analysis}

The experimental results are represented as mean \pm standard error of the mean. The data obtained in the studies were construed using one-way analysis of variance, followed by student t-test. 


\section{Results}

\section{Acute toxicity}

Oral administration of the oleaster leaf aqueous extract did not produce any mortality or signs of toxicity or behavioral changes during the 14-days of observation period in tested animals. Therefore, the approximate acute lethal doses $\mathrm{LD}_{50}$ were estimated to be higher than $2000 \mathrm{mg} / \mathrm{kg}$.

\section{Phytochemical screening}

The results of the qualitative phytochemical screening of the oleaster leaf aqueous extract showed the presence of a wide range of phytochemicals such as Tannins, Steroids, Flavonoids, Coumarins, Reducing sugars and Terpenoids. On the other hand, Alkaloids, Saponins and Anthraquinones were not present in the extract (Table 1).

\section{Determination of antidiarrhoeal activity}

\section{Effect of castor-oil-induced diarrhoeal}

The oleaster extract inhibited significantly $(\mathrm{P}<0.05)$ diarrhoea induced by castor oil according to the administrated doses, compared to the control group. The group treated with $400 \mathrm{mg} / \mathrm{kg}$ of the extract had the lowest frequency of defecation and the highest percentage of inhibition $77.08 \%$. There were no significant $(\mathrm{P}>0.05)$ differences between the percentage inhibition between rats treated with different extract doses and loperamide at $5 \mathrm{mg} / \mathrm{kg}$. Generally, the extracts inhibited diarrhoea in a dose-dependent manner (Table 2).

\section{Effect of castor oil-induced gastrointestinal motility}

The effect of oleaster extract on gastrointestinal transit of activated charcoal is shown in Table 3. There was a significant $(\mathrm{P}<0.05)$ decrease in the intestinal transit of activated charcoal in the extract treated groups compared to the control group. Percentage of inhibition of small intestinal transit in the extract treated groups by Oleaster extract was $57.15 \%$ at $100 \mathrm{mg} / \mathrm{kg}, 37.84 \%$ at $200 \mathrm{mg} / \mathrm{kg}$, $36.41 \%$ at $400 \mathrm{mg} / \mathrm{kg}$. The extract produced a dose dependant antimotility effect, whilst loperamide induced significant $(\mathrm{P}<0.05)$ inhibition in intestinal motility compared to vehicle treated group $40.34 \%$. However, no significant statistical difference was noted when compared with the other doses of the extract.

\section{Effect of castor oil-induced enteropooling}

The effect of the extract on castor oil-induced enteropooling is shown in Table 4. The results showed a significant decrease $(\mathrm{P}<0.05)$ between the volume of intestinal contents in the control group and the treated groups. The plant extract showed a dose dependant and a significant $(\mathrm{P}<0.05)$ reduction in the mean weight of the intestinal content with $34.11 \%, 50.58 \%$ and $57.54 \%$ at 100 , 200 and $400 \mathrm{mg} / \mathrm{kg}$ doses respectively, compared to the control Group. The highest percentage inhibition $59.85 \%$, was scored by the standard antidiarrhoeal drug, loperamide (5 mg/kg, p.o.).

\section{Discussion}

In the acute toxicity study, at a dose of $2000 \mathrm{mg} / \mathrm{kg}$ body weight, the extract produced no mortality and no adverse effects on the behavioral responses after 72 hours of observation and up to 14 days period; therefore, the LD50 of the aqueous extract of oleaster is higher than $2000 \mathrm{mg} / \mathrm{kg}$. This Indicates, that this dose may be considered safe when administered by oral route according to Global Harmonized Classification System. ${ }^{16}$ The results of phytochemical screening of the aqueous extract of Oleaster revealed the presence of Tannins, Steroids, Flavonoids, Coumarins, Reducing sugars and Terpenoids. It has been reported that this range of compounds has shown important pharmacological properties ${ }^{17}$ in treatment of several diseases, especially dysenteric and diarrhoeal disease. ${ }^{18}$ Therefore, a lot of research has focused on the production, and purification of these compounds agents. Thus, these phytochemicals could be the best source for the synthesis of various new drugs. ${ }^{19}$ The protective effect of the leaf aqueous extract of Oleaster in diarrhoea treatment was evaluated by using different diarrhoea experimental models in rat, a gastro-intestinal motility assay, a charcoal meal assay and a Castor oil-induced enteropooling test. In the castor oil induced diarrhoea model in rat, castor oil induces diarrhoea through its active metabolite, ricinoleic acid.

Table 1. Phytochemical constituents in oleaster leaf aqueous extract.

\begin{tabular}{lc} 
Phytochemical constituents & Relative presence \\
Alkaloids & - \\
Tannins & + \\
\hline Saponins & - \\
Flavonoids & + \\
\hline Coumarins & + \\
Anthraquinones & - \\
\hline Terpenoids & + \\
Steroids & + \\
\hline Reducing sugars & + \\
\hline +: presence of specific phytoconstituents; -: absence of specific phytoconstituents.
\end{tabular}

Table 2. Effect of oleaster leaf aqueous extract on castor oil-induced diarrhoea in rats.

\begin{tabular}{lccc} 
Group & Treatment/Group & Mean number of defecation in 6 h & Percentage protection (\%) \\
I & $2 \mathrm{~mL}$ normal saline+CO & $7.33 \pm 0.36$ & - \\
II & $100 \mathrm{mg} / \mathrm{kg}$ extract+CO & $2.83 \pm 0.33^{*}$ & 7.583 \\
\hline III & $200 \mathrm{mg} / \mathrm{kg}$ extract+CO & $2.33 \pm 0.23^{*}$ & 70.83 \\
IV & $400 \mathrm{mg} / \mathrm{kg}$ extract+CO & $1.83 \pm 0.18^{*}$ & 77.08 \\
\hline V & $5 \mathrm{mg} / \mathrm{kg}$ loperamide+CO & $2.16 \pm 0.18^{*}$ & 72.91 \\
\hline
\end{tabular}

*Statistically significant $(\mathrm{P}<0.05)$ compared to the control. CO, castor oil. 
The production of ricinoleic acid in the intestine induces irritation and inflammation of the intestinal mucosa resulting in the release of inflammatory mediators, leading to the release of prostaglandins. ${ }^{20}$ The prostaglandins released in the small intestines prevent the reabsorption of sodium chloride and water. ${ }^{21}$ Prostaglandins E are good diarrheagenic agents in experimental animals as well as in humans. Therefore, inhibition of prostaglandins biosynthesis delays castor oil-induced diarrhoea. ${ }^{22}$ The results of the present study revealed that Oleaster leaf aqueous extract exhibited significant $(\mathrm{P}<0.05)$ antidiarrhoeal activity against castor oil-induced diarrhoea in rats compared with the control group. The extracts had a comparable antidiarrhoeal activity to that of the standard drug loperamide and the most significant effect was observed at the dose of $400 \mathrm{mg} / \mathrm{kg}$. Moreover, our results directly demonstrate a significant inhibition $(\mathrm{P}<0.05)$ of castor oilinduced enteropooling with a reduction in weight and volume of intraluminal contents when compared to the control group. The maximal effect of the extract was similar to loperamide, which is one of the most widely employed drugs against diarrhoea disorder. ${ }^{23}$ Our findings match with the results of Msomi and Simelane. ${ }^{24}$ Moreover, Amabeoku and Bamuamba ${ }^{25}$ reported that leaf extract of Oleaster significantly $(\mathrm{P}<0.05)$ reduces gastrointestinal propulsion and secretion in castor oil-induced diarrhoea in mice. The inhibition of intraluminal fluid accumulation by Oleaster leaf aqueous extract might be due to the inhibition of prostaglandin synthesis. These results suggest that the aqueous extract inhibits prostaglandins biosynthesis. A previous study suggested that the analgesic and anti-inflammatory activities demonstrated by Olea europaea were due to the inhibition of prostaglandin biosynthesis, like that of non-steroidal anti-inflammatory drugs. Castor oil induced diarrhoea is related to stimulation of prostaglandins biosynthesis. ${ }^{26}$ Thereby, a previous study suggested that the colon anti-inflammatory status activities demon- strated by olive leaf extract improved the inflammatory status. This was due to the inhibition of prostaglandin biosynthesis like that of non-steroidal anti-inflammatory drugs. ${ }^{27}$

In the gastrointestinal motility in charcoal meal test, measurement of charcoal meal transit is carried out to find out the effect of drugs on peristaltic movement. Similarly to the findings in the castor oil-induced diarrhoea model, all doses of the plant extract showed a significant reduction in gastrointestinal transit using charcoal meal, with a dose- dependent pattern. This activity is comparable to that of loperamide used here as reference drug and acts by decreasing the transit velocity and increasing the capacity of the intestines to retain their fluids. ${ }^{28}$ So, the antidiarrhoeal effect of the plant extract may be attributed to the role of bioactive constituents such as tannins and flavonoids in the extract, which have already been reported for their antidiarrhoeal activity. ${ }^{29}$ Flavonoids present in anti-diarrhoea plants inhibit intestinal motility and hydroelectrolytic secretions. ${ }^{30}$ Tannins present in anti-diarrhoea plants denature proteins in the intestinal mucosa by forming protein tannates which may reduce secretion by making intestinal mucosa more resistant to chemical alteration. ${ }^{31}$ In that respect, different studies on the antidiarrhoeal properties of various plants support the hypothesis that tannins and flavonoids are responsible for the antidiarrhoeal effects. ${ }^{32}$

\section{Conclusions}

The present study has shown the safety of the plant extract when administered orally and that the leaf aqueous extract of Olea europaea L. subsp. europaea var sylvestris is a potential therapeutic option in the effective management of diarrhoea, thus justifying its use by our traditional herbal therapy.

Table 3. Effect of oleaster leaf aqueous extract on charcoal gastrointestinal transit in albino rats.

\begin{tabular}{lccccc} 
Group & Treatment/Group & $\begin{array}{c}\text { Total small } \\
\text { Intestine length }(\mathrm{cm})\end{array}$ & $\begin{array}{c}\text { Transit distance } \\
\text { of CH meal }(\mathrm{cm})\end{array}$ & $\begin{array}{c}\text { Percentage intestinal } \\
\text { transit }\end{array}$ & $\begin{array}{c}\text { Percentage } \\
\text { inhibition (\%) }\end{array}$ \\
I & $2 \mathrm{~mL}$ normal saline+CH & $106.88 \pm 0.87$ & $90.4 \pm 0.06$ & 84.60 & - \\
II & $100 \mathrm{mg} / \mathrm{kg}$ extract+CH & $100.6 \pm 0.46$ & $36.46 \pm 0.16$ & $36.25^{*}$ & 57.15 \\
\hline III & $200 \mathrm{mg} / \mathrm{kg}$ extract+CH & $104.1 \pm 0.31$ & $54.73 \pm 0.36$ & $52.57^{*}$ & 37.84 \\
IV & $400 \mathrm{mg} / \mathrm{kg}$ extract+CH & $104.56 \pm 0.28$ & $56.24 \pm 0.57$ & $53.79^{*}$ & 36.41 \\
\hline V & $5 \mathrm{mg} / \mathrm{kg}$ Loperamide+CH & $100.02 \pm 0.56$ & $50.48 \pm 0.12$ & $50.47^{*}$ & 40.34 \\
\hline
\end{tabular}

*Statistically significant $(\mathrm{P}<0.05)$ compared to the control. $\mathrm{CH}$, charcoal.

Table 4. Effect of oleaster leaf aqueous extract on castor oil-induced enteropooling.

\begin{tabular}{lccc} 
Group & Treatment/Group & Weight of intestinal content $(\mathrm{g})$ & Percentage inhibition (\%) \\
I & $2 \mathrm{~mL}$ normal saline+CO & $3.27 \pm 0.03$ & 34.11 \\
II & $100 \mathrm{mg} / \mathrm{kg}$ extract+CO & $2.24 \pm 0.04^{*}$ & 50.58 \\
\hline III & $200 \mathrm{mg} / \mathrm{kg}$ extract+CO & $1.68 \pm 0.05^{*}$ & 57.54 \\
IV & $400 \mathrm{mg} / \mathrm{kg}$ extract+CO & $1.44 \pm 0.04^{*}$ & 59.85 \\
\hline V & $5 \mathrm{mg} / \mathrm{kg}$ Loperamide+CO & $1.36 \pm 0.04^{*}$ & \\
\hline
\end{tabular}

*Statistically significant $(\mathrm{P}<0.05)$ compared to the control. $\mathrm{CO}$, castor oil. 


\section{References}

1. Green PS. A revision of Olea L. (Oleaceae). Kew Bull 2002;57:91-140.

2. Wainstein J, Ganz T, Boaz M, et al. Olive leaf extract as a hypoglycemic agent in both human diabetic subjects and in rats. J Med Food 2012;15:605-10.

3. Al-Attar AM, Alsalmi FA. Effect of Olea europaea leaves extract on streptozotocin induced diabetes in male albino rats. Saudi J Biol Sci 2017 [In press].

4. Richard SA, Black RE, Gilman RH, et al. Diarrhea in early childhood: short-term association with weight and long-term association with length. Am J Epidemiol 2013;178:1129-38.

5. Olatokunboh AO, Mofomosara SH, Ekene OA. Evaluation of the antidiarrhoeal effect of Lannea welwitschii Hiern (Anacardiaceae) bark extract. Afr J Pharm Pharmacol 2010;4: 165-9.

6. Saralaya MG, Patel P, Patel M, et al. Antidiarrhoeal activity of methanolic extract of Moringa oleifera lam roots in experimental animal models. Int J Pharmac Res 2010;2:35-9.

7. Guede GF, Vangah MM, Bonga G, Souza Cd. Activity and antibacterial plant extract against opportunistic germs in AIDS. Rev Med Pharm 1995;9:13-9.

8. Clark JD, Gebhart GF, Gonder JC, et al. The 1996 guide for the care and use of laboratory animals. ILAR J 1997;38:41-8.

9. Organization for Economic Cooperation and Development. OECD Test guidelines for the chemicals. 2008. Available from: http://www.oecd.org/env/ehs/testing/oecdguidelinesforthetestingofchemicals.htm

10. Harborne JB. Phytochemical methods: a guide to modern techniques of plant analysis. London, UK: Chapman \& Hall; 1973.

11. Evans WC. Trease and Evans' Pharmacognosy. 13th ed. London, UK: Bailliere Tindall; 1989.

12. Organization for Economic Cooperation and Development. Guideline for testing of chemicals: acute oral toxicity- acute toxicity class method 423. 2001. Available from: https://ntp.niehs.nih.gov/iccvam/suppdocs/.../oecd_gl423.pdf

13. Awouters F, Niemegeers CJE, Lenaerts FM, Janssen PAJ. Delay of castor oil diarrhoea in rats: a new way to evaluate inhibitors of prostaglandin biosynthesis. J Pharm Pharmacol 1978;30:41-5.

14. Chitme HR, Chandra R, Kaushik S. Studies on anti-diarrhoeal activity of calotropis gigantear in experimental animals. J Pharm Pharmaceut Sci 2004;7:70-5.

15. Robert A, Nezamis J, Lancaster C, et al. Enteropooling assay A test for diarrhea produced by prostaglandins. Prostaglandins 1976;11:809-28.

16. United Nations. Globally Harmonized System of Classification and Labelling of Chemicals (GHS). 4th ed. New York and Geneva: United Nations; 2011. Available from: https://www.unece.org/fileadmin/DAM/trans/.../ghs/ghs.../STSG-AC10-30-Rev4e.pdf

17. Polya G. Biochemical targets of plant bioactive compounds: A pharmacological reference guide to sites of action and biological effects. 1 ed. New York, NY: Taylor \& Francis; 2003.

18. Komal S, Kumar S, Rana A. Herbal approaches for diarrhea: A review. Int Res J Pharm 2013;4:31-8.

19. Wadood A, Ghufran M, Jamal SB, et al. Phytochemical analysis of medicinal plants occurring in local area of Mardan. Biochem \& Analytic Biochem 2013;02:1-4.

20. Salako OA, Akindele AJ, Shitta OM, et al. Antidiarrhoeal activity of aqueous leaf extract of Caladium bicolor (Araceae) and its possible mechanisms of action. J Ethnopharmacol 2015;176:225-31.

21. Tunaru S, Althoff TF, Nusing RM, et al. Castor oil induces laxation and uterus contraction via ricinoleic acid activating prostaglandin EP3 receptors. Proc Natl Acad Sci USA 2012;109:9179-84.

22. Manikanta B, Varma PR, Krishna PV, et al. Physicochemical evaluation of Aurucaria columnaris. J Chem Pharmaceut Sci 2014; 7:194-6.

23. Kabir MS, Hossain MM, Kabir MI, et al. Antioxidant, antidiarrhoeal, hypoglycemic and thrombolytic activities of organic and aqueous extracts of Hopea odorata leaves and in silico PASS prediction of its isolated compounds. BMC Complement Altern Med 2016;16:474.

24. Msomi NZ, Simelane MBC. Olea europaea subsp. africana (Oleaceae). In: El-Shemy HA, ed. Active ingredients from aromatic and medicinal plants. London, UK: InTechOpen; 2017. pp 159-74.

25. Amabeoku G, Bamuamba K. Evaluation of the effects of Olea europaea subsp. africana (Mill.) PS Green (Oleaceae) leaf methanol extract against castor oil induced diarrhoea in mice. J Pharm Pharmacol 2010;62:368-73.

26. Pramod PS, Vishnu AN. Evaluation of antidiarrhoeal activity of Ficus Glomerata in castor Oil induced diarrhoea in rats. $\mathrm{J}$ Sci 2011;1:26-30.

27. Vezza T, Algieri F, Rodriguez-Nogales A, et al. Immunomodulatory properties of Olea europaea leaf extract in intestinal inflammation. Molec Nutrition \& Food Res 2017;61.

28. Han SH, Park K, Kim EY, et al. Cactus (Opuntia humifusa) water extract ameliorates loperamide-induced constipation in rats. BMC Complement Altern Med 2017;17:49.

29. Labu ZK, Laboni FR, Mamun MMAA, Howlader MSI. Antidiarrhoeal activity and total tannin content of ethanolic leaf extract of Codiaeum variegatum. Dhaka Univ J Pharm Sci 2015; 14:87-90.

30. Di-Carlo G, Autore G, Izzo A, et al. Inhibition of intestinal motility and secretion by flavonoids in mice and rats: Structure-activity relationships. J Pharm Pharmacol 1993;45:1054-9.

31. Galvez J, Crespo ME, Jimenez J, et al. Anti-diarrhoeic activity of quercitrin in mice and rats. J Pharm Pharmacol 1993;45:157-9.

32. Tadesse E, Engidawork E, Nedi T, Mengistu G. Evaluation of the anti-diarrhoeal activity of the aqueous stem extract of Lantana camara Linn (Verbenaceae) in mice. BMC Complement Altern Med 2017;17:190. 